Adrian O. Mandzy

\title{
THE 1649 BATTLEFIELD OF ZBORIV: IDENTIFICATION OF PLACE AND PLANNING RECONSTRUCTION
}

\author{
Associate Professor of History, Morehead State University, Kentucky, USA \\ e-mail:a.mandzy@morehead-st.edu \\ ORCID: 0000-0001-7831-1560
}

Received: 15.07.2019/Revised: 11.09.2019/Accepted: 12.09.2019

(C) Mandzy A. O., 2019

Abstract. In 2001, dr. A. Mandzy, working with scholars in both Poland and Ukraine, initiated the Cossack Battlefield Commission to explore and study Cossack battlefields. The battlef ield near Zboriv 1649 was chosen as the object of survey. Much like previous excavations at the Berestechko Battlefield, the Zboriv project made heavy use of historical records, cartographic evidence and archaeological fields testing methods. Beginning in 2002, the group of researches, working under promotion dr. Mandzy in conjunction with the I. Kryp'iakevych Institute of Ukrainian Studies and Department of Architecture and Conservation of Lviv Polytechnic University, the regional power of preservation of historical and cultural monuments for the Ternopil Oblast, began a joint survey, the purpose of which was identifying any possible remaining cultural resources associated with the military events of 1649 . Material of this survey was the basis for hypothetical planning reconstruction of 1649 field fortifications lines.

Key words: town of Zboriv, battlefield, Cossack and Polish Army, $17^{\text {th }}$ century, hypothetical reconstruction, field fortification.

\section{Introduction}

The Battle of Zboriv is one of the major events in Ukrainian and Polish history. Following two days of bitter fighting, the battle came to an end with the signing of the Treaty of Zboriv. This Treaty recognized the de facto autonomy of three Ukrainian provinces and established an independent Ukrainian Cossack principality.

\section{Analysis of publications about Zboriv battle}

Initial reaction to the treaty was positive from both the Commonwealth and the Cossacks. The royal chancellery of Commonwealth prepared an official account about a glorious expedition and a felicitous peace that was published in newspapers throughout Europe (Teodor Mats'kiv, 1985) Galaktion, the Macedonian metropolitan, who claimed to have had a meeting with the Cossack leader, also wrote of a great Cossack victory, where the king "submitted and made obeisance" (Akty otnosiashchiesia k istorii Iuzhnoi i Zapadnoi Rossii, 1861). According to Lukash Klymovsky, a doctor in the Cossack camp, the king had been sorely beset at Zboriv and wrote to Khmelnytskij to make peace. The hetman obeyed him on the condition that there be Cossack towns as far as the Slutch River and Starokonstiantyniv and as far as Bar and the Dnister River. According to the L'viv Chronicle, the king himself asked for peace and promised the Cossacks rights and privileges (volnosti). (Akty otnosiashchiesia k istorii Iuzhnoi i Zapadnoi Rossii, 1861). 
In the years that followed, both sides continued to be interpret the Treaty as a major victory. In 1663 , for example, Pierre Chevalier wrote that the withdrawal of Khmelnytskij and the Khan from Zboriv greatly pleased the king, who escaped from such danger so cheaply. (Baraboj, A. Z., Bevzo O. A., eds., P'ier Sheval'e (Pierre Chevalier), 1993) The Litopys Samovydtsia states that the Zboriv agreement was a positive development for the Cossacks. According to this source, the monarchy was besieged without any hope of rescue and was only saved by the grace of Khmelnytskij, who did not want to send a Christian king into Islamic captivity (Dzyra, 1971). A little more than a half-century after the signing of the Treaty of Zboriv, the Cossack hetman Philip Orlyk wrote that since 1649, Ukraine was recognized as a principality by all of Europe (Orlyk, 1958).

This idea continues to be expressed in the late eighteenth/early nineteenth century work, Istoria Rusiv. (Konyskogo, 1846) Written by a nobleman under the influence of the Enlightenment and the ideal that each nation has the right to follow its particular destiny, the published manuscript is a political tract, the focus of which is the 1648 revolt. The Treaty of Zboriv is described in detail and seven major points of the treaty are listed. Following the signing of the treaty, according to the Istoria Rysov, Khmelnytskij disbursed his army and traveled to Kiev where, with great pomp and ceremony, he celebrated his victory.

In the light of nineteenth century romantic and populist movements, new interpretations developed about the Zboriv Treaty. Unlike earlier works, which were written by members of the elite and the descendants of the Cossack officer corp, this generation of scholars saw itself as part of the local indigenous population. Much like other intellectuals in $19^{\text {th }}$ century Europe, they developed a fascination with the narod, or nation of people. As such, they rejected the status quo and its emphasis on the victories of dynastic rulers. This group of intellectuals and social activists sought to critically examine how historical events influenced all of the social and economic classes, especially the effects on the poor and the workers. Khmelnytskij now would be judged on how well his actions helped the people, and not in his ability in establishing a Cossack state.

Perhaps the first scholar to look at the events from this new school of though was Mykola Kostomarov. Kostomarov rejected the perception of Khmelnytskij as national liberator and focused on the misery the wars had on the Ukrainian people. As to the importance of the Treaty of Zboriv in the establishment of the Cossack hetmantate, Kostomarov simply states that the Zboriv Treaty was twenty years too late to satisfy the needs of the Rus' nation (Kostomarov, 1990). That such a treaty would have been acceptable to Kostomarov earlier indicates that the text of the treaty itself was not at fault, but only that by 1649 the circumstances had changed to where it was unacceptable.

Other nineteenth century historians developed Kostomarov's ideas further. Volodymyr Antonovych saw the Treaty as another of Khmelnytskij's errors which brought with it great injury to the Ukrainian people (Antonovych, 1885). A few years later, one of Antonovych's students, Mykhailo Hrushevsky saw the Zboriv Treaty as not just an error of judgment, but as a betrayal of the Cossack hetman by his Tatar ally. In a chapter entitled "The Zboriv agreement and its hopelessness", Hrushevsky points out that it was the Khan who accepted the Polish proposal for a peaceful resolution to the ongoing hostilities. After accepting payment, the Khan told Khmelnytskij that if he did not make peace with the Commonwealth, then the Khan would join with the Poles and turn against the Cossacks. As part of the agreement, the Tatars could collect slaves on their return home. According to this interpretation, however, the taking of Ukrainians into Tatar captivity was not the only dark stains of the Treaty. According to Hrushevsky, the Zboriv Agreement severely truncated Cossack territory and those excluded from the register had to return to their former subject status. "For the broad masses, the results of the uprising were immediately struck out; all their efforts and sacrifices all their blood and suffering were turning out to have been in vain" (Antonovych, 1885).

Another contemporary of Hrushevsky, Iavornyts'kyj also points out the failings of the Treaty. Iavornyts'kyj devotes little attention to Khmelnytskij in this three volume history of the Cossacks, but noted that shortly after the signing of the Zboriv Treaty all of the Ukrainian masses were disappointed with the Cossack leader. As a result of this disappointment, according to Iavornyts'kyj, an unnamed Cossack titled himself as the Hetman of Ukraine and began to recruit Zaporizhian Cossacks to his side (Antonovych, 1885). Thus, for this group of scholars of the late nineteenth and early twentieth century, Zboriv failed because it did not protect the entire Ukrainian nation. 
Not all published works, however, followed this trend. Mykola Arkas's illustrated 1908 popular History of Ukraine-Rus paints a very different account (Antonovych, 1885). Written for the masses, this account reflects the world view of Tzarist Black Sea naval officer (and later administrator) who's family could trace their roots to the Cossack officer class. According to this work, Khmelnytskij personally brought an end to the fighting after completely destroying all that stood in his way. To highlight the degree of victory achieved at Zboriv, Arkas included an illustration entitled "Bohdan Khmelnytskij after the Battle of Zboriv". This print shows Khmelnytskij mounted heroically on a large black stallion. The hetman is flanked by mounted Cossacks and cheering peasants, while below his feet are discarded Polish arms.

Throughout the nineteenth century, as Polish patriots tried to restore the Kingdom of Poland, popular histories focused on past military triumps and losses. Of all the published works, Henryk Sienkiewicz's 1884 historical novel With Fire and Sword was the most important in establishing a Polish stereotype for the events of 1649. While the romantic protrails of heroic Poles and evil Cossacks are of limited academic value, the novel was critical in perpetuating Polish national identity. The work remains manditory reading in Polish schools and is one of the most popular works of Polish literature. As the novel and its many film adaptations continue to influence the Polish subcouncious, the climatic interpretations of the heroic Siege of Zbarazh and the signing of the Treaty of Zboriv with the Cossacks can periodically be recognized in Polish popular culture. Yet for all the novel's fictional liberties, the novel ends the story of the rebellion where most Ukrainian historians had previously recognized the beginning of the Cossack state - that of the 1649 Treaty of Zboriv.

The Polish historian Ludwik Kubala deals with the Siege of Zbarazh, the Battle of Zboriv and the Treaty in a historical-popular work. According to Kubala, the Treaty was hard on Khmelnytskij, as both the 40.000 Cossack register and his title of hetman were of no importance to an individual who already had power and authority (Kubala, 1909) In other general military studies, such as by Tadeusz Korzon, the Treaty was considered to be benificial to the Commonwealth, as it allowed the Tatars to take slaves on their return home in place of unpaid taxes. The Cossacks, in turn, were satisfied with the raising of the Cossack register to 40.000 and the granting of the title Hetman and Elder of Cheheryn to their leader. (Korzon, 1912).

In the years following the First World War, new interpretations of the Zboriv Treaty emerged. Ukrainian Marxist historians, such as Mykhailo Pokrovsky and Matvij Iavorsky, viewed the Treaty of Zboriv along class lines. (Iavorsky, 1928), (Pokrovsky, 1933) According to this anti-Rossian imperialist Marxist interpretation, Zboriv, along with the Bila Tserkva Accord, provided the Cossack elite with a way of controlling the masses. Non-Marxist historians, such as Viacheslav Lypynsky argued that the events at Zboriv were the first steps in reestablishing the Ukrainian Cossack state (Lypynsky, 1920). George Vernadsky wrote that the Zboriv Treaty was a "major achievement for the conservative core of the starshyna" and "it created an autonomous Cossack state within the framework of the kingdom of Poland" (Vernadsky, 1941). Others, such as Stepan Tomashivsky, challenged some of the basic principles of the negotiations that lead up the signing of the Zboriv Treaty. Tomashivsky pointed out that the king decision to open negotiations with the hetman was an admission of Poland's defeat (Tomashivsky, 1913). The fact that the Polish state later tried to hide this detail lends support to argument that the Commonwealth was politically overwhelmed.

Perhaps the most detailed account of the battle come from the Polish historian Ludwig Frąś. Making use of predominantly published sources, Frąs study contains the Polish order of battle, including the types of troops involved, the names of their commanders and their role in the engagement. Unlike many scholars, however, Frąs does not discuss the Treaty in any detail in this study. Rather, the author claims that after two days of fighting, the battle could have gone either way, depending on the whim of the Tatar Khan. In a separate study published the same year, however, Frąs states that the Khan forced Khmelnytskij to sign a treaty because it looked like the Battle at Zboriv was turning into a long, protracted siege, just like at Zbarazh (Frą́s 1932).

In the 1920s, Ivan Kryp'iakevych conducted an on-site study the Zboriv battlefield and later published five separate accounts about the events of $1649{ }^{1}$ Initially, Krypiakevych noted that the treaty did not provide

${ }^{1}$ His most detailed description appeared in Zhyttia i Znannia, no. 10-11, L'viv, 1929, while a later account published in the Litopys Chervonoi Kalyny, no. 10, L'viv, 1931, includes two maps, one which showed the disposition of forces at the time of the initial ambush, and second illustrated the attacks of the second day. These maps have often been republished and continue to be used by Polish and Ukrainian scholars to illustrate how the battle transpired. 
Ukrainians with everything that the Ukrainian nation desired, but that it did provide Ukraine with its own army and a base from which an independent Ukrainian state could emerge. A few years later, when writing the Cossack section in the Istoria Ukrains'koho Vijska, Kryp'iakevych interpreted the Treaty of Zboriv as providing the legal bases for the Cossack state (pravni osnovy kozats'kij derzhavi). Later works, published during the height of Stalin's hold on academia, downplayed the statebuilding achievements. In Krypiakevych's biography of the Cossack leader, the author focused on the betrayal of Khmelnytskij by his Tatar allies and the anti-cossack role played by the Ukrainian nobleman Adam Kysil in the actual treaty negotiations. (Kryp'iakevych, 1990).

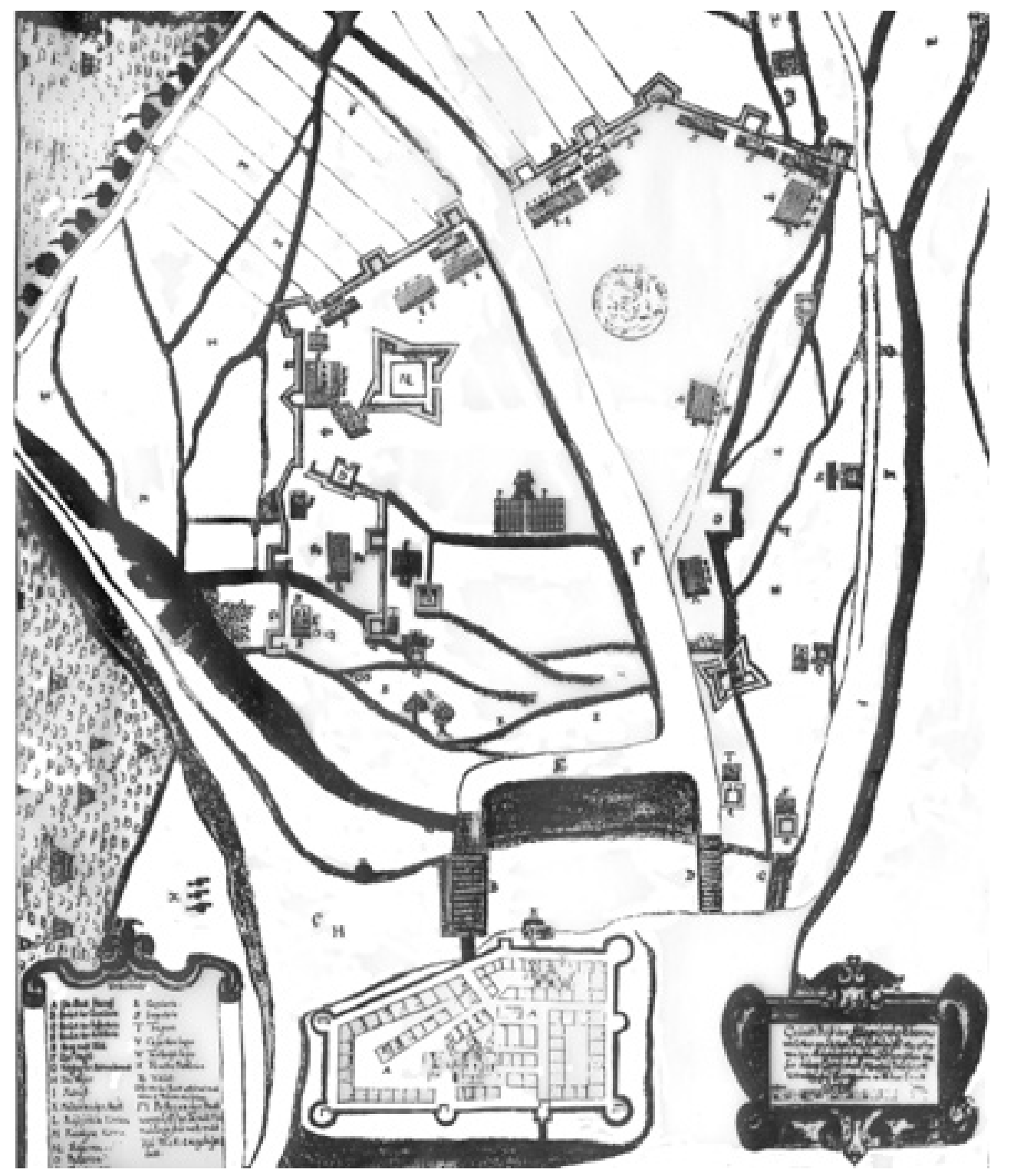

Fig. 2. 1649 Map of Zboriv, from Alexandrowicz

During and after the Second World War, political pressure to provide a pro-Russian Ukrainian hero resulted in exultation of Bohdan Khmelnytskij ${ }^{2}$. Previous Marxist interpretations of a feudal lord who sold

${ }^{2}$ In October 1943, the Soviets created the Order of Bohdan Khmelnytsky, the only Soviet military order to include a nonRussian hero in Stalin's pantheon of "our great ancestors". As illustrated in a letter from Khrushev to Stalin, Khmelnytsky was chosen not because he fought for Ukraine's liberation, but because of the union of Ukrainian and Russian peoples. Serhy Yekelchyk, "Stalinist Patriotism as Imperial Discourse: Reconciling the Ukrainian and Russian "Historic Pasts", 1939-45", Kritika, 3 (1): 51-80, winter 2002, p. 69. 
out the peasants to Russian imperialism were swept aside and history texts glorified a military hero who had a single clear vision - reunification with Moscow. In this politically inspired view, Khmelnytskij single-mindedly pursued reunification over all other concerns; a dream which was fulfilled with the 1654 Pereiaslav Agreement (Kozachenko, 1954). Thus, in keeping with what John Basarab refers to as the 1654 thesis, it was with the signing of the Pereiaslav Agreement that the Ukrainians and the Russians began a successful struggle that culminated with the overthrow of the capitalist class and the establishment of the Soviet Union (Basarb, 1982). In this interpretation, the Pereiaslav Agreement serves as the cornerstone of the Soviet national myth.

Not surprising, the Soviet state apparatus sponsored countless public activities and academic publications on the three-hundred-year anniversary of the Pereiaslav Agreement. Given the importance of Pereiaslav for the Soviet identity, all other treaties and alliances were interpreted as merely temporary arrangements on the way to reunification. Although authors previously acknowledged the conclusion of the Cossack uprising with the establishment of the Cossack Principality in 1649, the now rechristened "War of National Liberation», reached its natural conclusion five years later at Pereiaslav. In this Soviet national myth, all other alliances and treaties were irrelevant and Treaty of Zboriv was but a steppingstone to the goal of reunification.

While the vast majority of Soviet scholars downplayed the Treaty of Zboriv, some scholars outside the Soviet sphere of influence attempted to develop their own interpretations. Teodor Mats'kiv's article on the treatment of the Zboriv Agreement in contemporary German and English sources states that in the face of the overwhelming enemy the Poles opened negotiations with the Khan in order to bring him to their side (Mats'kiv, 1985). According to Mats'kiv, the Khan agreed to the crown's overtures because the Muscovite Cossacks attacked Tatar lands and the Khan did not want a strong Cossack state. Mats'kiv goes on to discuss problems with existing copies of the Treaty and points out that in an unmodified text of the Treaty which was published in Germany, the Cossacks of Kiev, Chenihiv, Vinnytsia and all of Ukraine are to be free. Rather than going on to explore the implications of this agreement, Mats'kiv fell back on the nineteenth century tradition and states that Zboriv "did not reflect the actual achievements of the Cossack army and the great expectations of the Ukrainian national masses who stepped under the banner of Khmelnytskij in the fight for freedom" (Teodor Mats'kiv, 1985). Although Mats'kiv recognizes that the Treaty was important in the history of Polish Ukrainian relations, the focus of his argument shifts in defending the fact that Ukraine was a protectorate of Poland. He concludes his article with a discussion of how common protectorates were in the seventeenth century and quotes a German dissertation that paints Khmelnytskij as a de facto sovereign ruler. Rather than quoting from a contemporary primary source, which recognizes the achievement of Cossack autonomy, Mats'kiv curiously relies on a German study that appeared in the early years of the Nazi regime to make his argument for the establishment of Ukrainian Cossack state.

Other western scholars writing during the Cold War looked at the Treaty of Zboriv from either the initial historical interpretation that focused on recognition of autonomy (as argued by Orlyk, Arkas and Lypinsky) or from the narod school of though (best summarized by Hrushevskij). George Gajecky argues that the Cossack state was created in 1648, but that it was only after the Treaty of Zboriv that the Polish Diet recognized the Cossack territory as an autonomous unit of the Polish-Lithuanian Commonwealth (Gajecky, 1978). Frank Sysyn noted that although the articles of the Zboriv Treaty did not include all the Cossack demands, they represented an undeniable triumph for the Cossacks and that the 40,000 man Cossack army ensured Khmelnytskij as an almost independent ruler of Ukraine (Sysyn, 1985). Others, such as Orest Subtelny, focus their attention on Hryshevsky's argument of a Tatar betrayal (Subtleny, 1988).

In Soviet Ukraine, the 1654 thesis remained the cornerstone of all research connected with the seventeenth century. Though Mykhailo Braichevsky questioned the validity of the 1654 thesis in the late 1960s, the Treaty of Pereiaslav continues to draw the attention of scholars and politicians into the first decade of the twenty-first century (Braichevsky, 1972). The three hundred and fifty year anniversary of the 1648 rebellion drew little notice, but more then ten years after independence, Ukrainian President 
Leonid Kuchma announced national celebrations to mark the Pereiaslav Accord. Many Ukrainians were offended with this planned celebration and President Kuchma drew the ire of scholars throughout the world.

In independent Ukraine, historians looking at the Battle and Treaty of Zboriv often seek ways to balance the achievement of recognition of autonomy with the criticisms presented by the narod school of thought by drawing attention to the nuances of the negotiations. Sveshnikov's interprets the Treaty as a result of Crimean Tatar betrayal and thus any achievements brought by the Treaty were irrelevant, since the nation was not freed from oppression by the nobility and the Catholic Church (Sveshnikov, 1993). According to Shevchenko, who wrote the introduction to the 1995 edition of the 1649 Cossack Register, the khan wanted to continue the war in Ukraine, so that he could collect slaves and receive payments from the crown (Shevchenko, 1995). Shevchenko also noted that the resulting Cossack Register confirmed Cossack rights in that they did not fall under the jurisdiction of the starost, namisnykiv and the nobility. Cossacks not listed in the register, however, must submit to the will of the king's representatives and their masters (Shevchenko, 1995). According to the Ukrainian Cossacks, a Small Encyclopedia, the Khan wanted to avoid the complete destruction of Poland, because he did not want to see Ukraine become a strong, independent Orthodox $s^{3}{ }^{3}$. The encyclopedia also states that Khmelnytskij was forced to accept unfavorable terms for Ukraine which did not reflect the achievements of the Cossack army nor the wider hopes of the national Ukrainian masses ${ }^{4}$. According to Valerij Smolij and Valerij Stepankov, Khmelnytskij was forced into signing the Treaty, but his requests to the king foresaw recognition of a Ukrainian state within the boundaries set by the document (Smolij, V., Stepankov, V., 203). Natalia Iakovenko noted that the Poles began discussions with the Tatars without Khmelnyts'kij's participation and that the 40.000 Cossack register was requested by the khan's vizar (Yakowenko, 2006).

With the end of the Cold War, Polish scholars began to look at the Cossack Wars. In the 1990s, popular accounts multiplied as Poles and Ukrainians began to discuss their shared and often misunderstood heritage. While older academic works were republished, perhaps the most important publication was the printing of two historical maps from 1649 (Alexandrowicz, 1995). These two maps, one of the Siege of Zbarazh and the other of the Battle of Zboriv were first listed in the 1976 catalogue of maps held in the National Library in Berlin greatest, but their first publication was delayed until 1995.

The map of Zboriv is rather detailed and shows the disposition of troops (Fig. 1) (Alexandrowicz, 1995). The earthen defenses are illustrated rather vividly, as is the position of the Cossack gun battery, and a less detailed plan of the town of Zboriv itself is also included. The map, according to Alexandrowicz, is about 1:3000, but is rather vague in regards to the local topography. The location of both the Cossack and Tatar camps are though to be rather schematic and the rivers are shown in only approximate locations. As the map was drawn during the battle, some inaccuracies of scale were inevitable, but the disposition of enemy forces are not though to be in scale with the Polish defense line.

Perhaps the most interesting post-Soviet interpretation of these events comes from a military historian, Ivan Storozhenko, who provides a somewhat different understanding of the Treaty. According to Storozhenko, it was Khmelnytskij who initiated the diplomatic talks with the king and used the khan as his intermediary (Storozhenko, 1996). As a rebel, and most likely not even a recognized member of the nobility, Khmelnytskij could not negotiate directly with his monarch. As Khmelnytskij did not want the destruction of the Commonwealth, he needed a political resolution to the ongoing conflict. By negotiating a treaty, he was able to achieve outside recognition of his authority and begin to bring stability and order into his domain.

While Storozhenko clearly addresses the issue of the Treaty from the state building school of thought (he quotes Lypyns'kyj in his text), he begins to contradict himself at the end of the chapter.

3 “The Battle of Zboriv 1649”, Ukrainian Cossacks, a Small Encyclopedia, Zaporizhzhia State University, Geneza, Kiev, 2002, p 170 .

4 “The Treaty of Zboriv 1649”, Ukrainian Cossacks, a Small Encyclopedia, Zaporizhzhia State University, Geneza, Kiev, 2002, p 171. 
According to Storozhenko, Cossack victory could still be achieved after the initial attack, but once the Polish forces constructed earthen field fortification, military success would require "significant effort" (Storozhenko, 1996). A possible explanation for the failure of the Cossack infantry was their delayed arrival from Oserna (14 kilometers away according to Storozhenko). While the distance from Oserna is less than ten kilometers, the main point of criticism is Storozhenko's thesis itself. If Khmelnytskij sought a political resolution of the conflict, then he had no need to seek a military solution. Success on the battlefield, as achieved in 1648, did little to bring a consolidation of Cossack power. Further military actions, however, would most likely lead to the capture or even death of the monarch, neither which would allow Khmelnytskij to attain a political resolution that would be confirmed by all levels of the Polish government. Only be signing a treaty could Khmelnytskij become the legally recognized ruler of Ukraine.

\section{Methodology of studies and presentation of main results}

In spite of the significant scholarly attention the events at Zboriv have received, a number of questions remain unanswered. In pursuit of a better understanding of the Battle and the Treaty of Zboriv, in 2002 the author organized a group of Ukrainian, Polish and American students and scholars for the purpose of undertaking a battlefield survey project ${ }^{5}$. Since the primary documentary record is fragmentary at best and it is unlikely that new literary sources will be uncovered in the near future, the author applied a holistic multidisciplinary approach, one that makes use of archaeological, historical, topographical and cartographic evidence. The results from the 2002 field season, along with data collected in 2004 and 2006, have sown the seeds of yet another possible interpretation of the events of 1649 (Fig. 2).

While interest in former fields of conflict has a long and complex history, before the 1980s no method existed for scholars to look at entire battlefields. Previously, historians often included maps of an engagement, but at times they bore little resemblance to the local topography. Archaeologists focused their energies to the excavation of particular features, such as campgrounds, siege lines, hospitals and burials, but lacked a way of dealing with the entire battlefield ${ }^{6}$. At times, however, particularly rich mass burials have been excavated, such as at the graves from the 1361 Battle of Wisby and the 1651 Battle of Berestechko (Thordeman, B., Noörlund P. and Bo E., 1939) (Sveshnikov, 1993). In most cases, however, the dead were stripped of all material goods before being buried.

Archaeologists who relied on traditional testing methods of digging in depth rarely have succeded in identifying resources related to military engagements. Using traditional archaeological field methods at the American Civil War First Manassas (Bull Run) battlefield, for example, "only one artifact was found by shovel testing, while several hundred were found using metal detectors" (Babits, 2001). Not surprisingly, when in the mid-1990s, a group of young archaeologists employed traditional testing methods at the Zboriv battlefield, they failed to find any material from the seventeenth century battle ${ }^{7}$.

Following a fire at the Little Big Horn National Battlefield, archaeologists Doug Scott and Richard Fox began a program to look at the entire field of conflict (Scott, Douglas D., Richard A. Fox, Jr., 1987) (Scott, D. D., R. A. Fox, Jr., M. A. Connor and D. Harmon, 1989). To do so, they used medal detectors to locate artifacts and global positioning satellites or more commonly known as GPS, to plot the locations of the recovered artifacts. This data, coupled with extensive primary historical research and topographic data, provided scholars with a means of exploring battlefields.

\footnotetext{
${ }^{5}$ This research program was made possible by a Fulbright-Hays Faculty Research Fellowship and through the support of Morehead State University.

${ }^{6}$ First the territory of a battlefield, especially a post-medieval battlefield, can be a quite large, and secondly, artifacts are generally not distributed in depth.

${ }^{7}$ World War One artifacts from these excavations are on display at the local museum in Zboriv.
} 


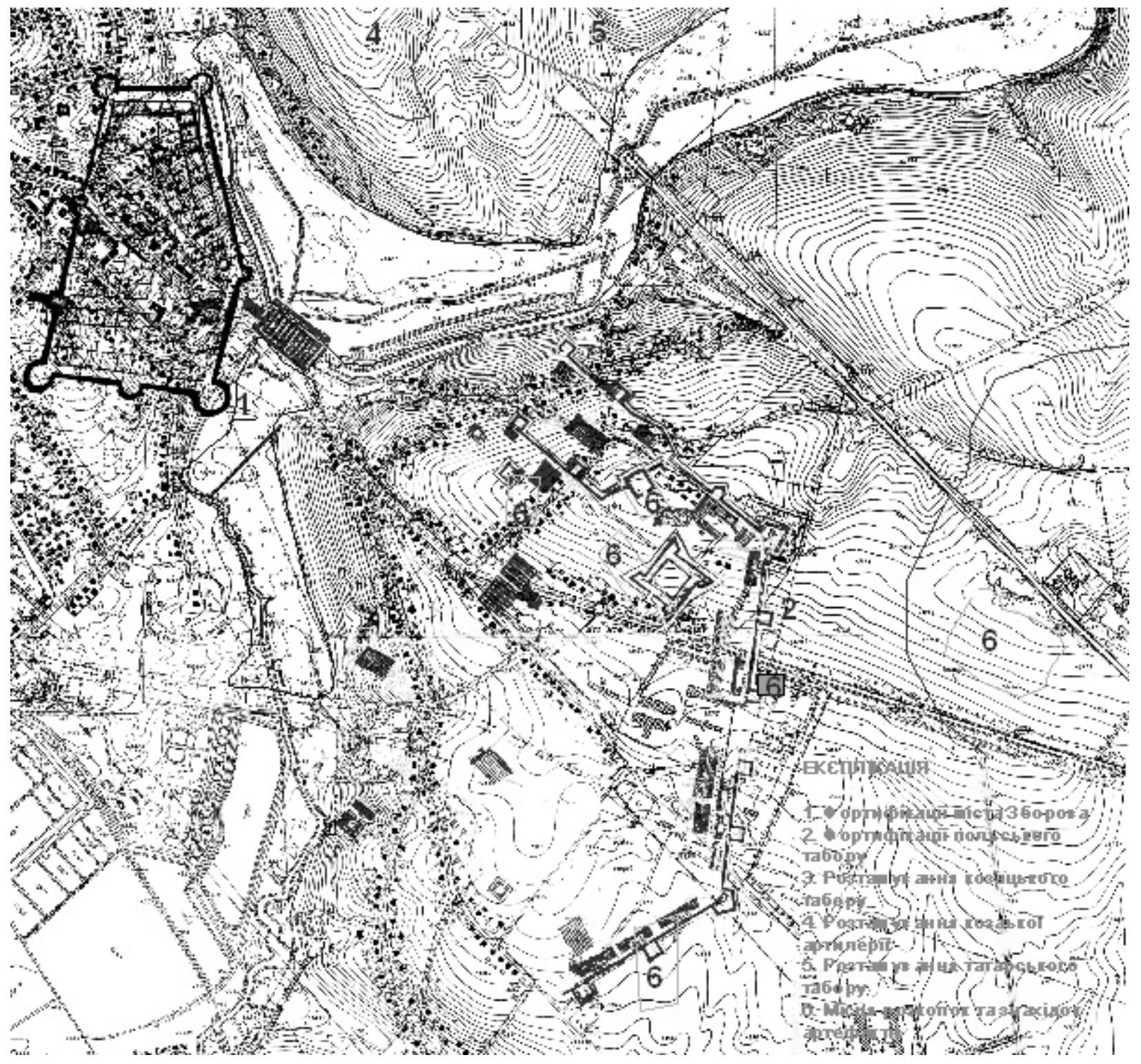

Fig. 2. Composite Battlefield Map

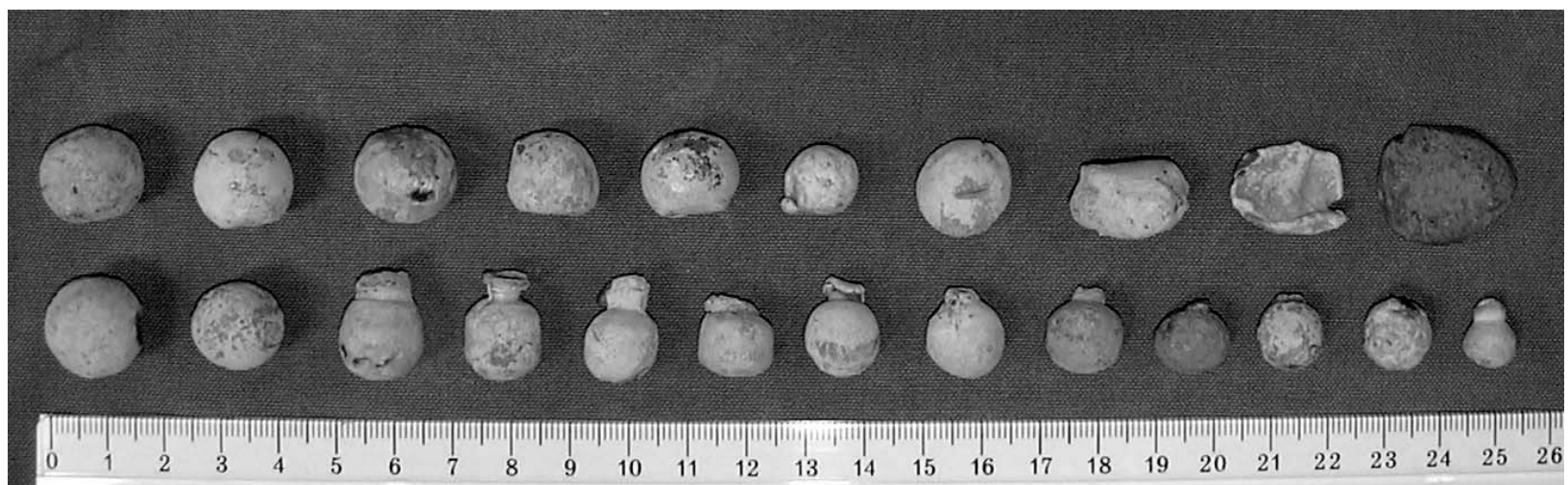

Fig. 3. Examples of $17^{\text {th }}$ century ammunition

Building on the success of the Little Bighorn project, scholars followed the methodology outlined by Scott and began using metal detectors to survey other battlefields. By plotting the distribution of artifacts along a several square mile $\mathrm{X}$ and $\mathrm{Y}$ grid, it became possible to identify patterns across great distances. 
Superimposing this grid on contemporary and historic maps further allowed correlation with primary descriptions of the battle and the local topography. The resulting dataset provided scholars with a much more accurate view of how the course of a battle developed and how troops reacted under fire. Other scholars also contributed to the growing field of battlefield research. In determining whether individual musket balls were dropped or fired, Dan Sivilich developed a "firing fan" model that predicted from which possible direction and location the shot originated (Sivilich). Using a similar approach, William Lee identified the area of fired shot behind a concentration of dropped shot as the rounds that overshot their intended targets (Lees, 1994). The repeated success of this approach has spanned similar studies in other parts of the world (Babits, 2001).

In 2001, the author, working with scholars in both Poland and Ukraine, initiated the Cossack Battlefield Commission to explore and study Cossack battlefields ${ }^{8}$. Much like Svechnikov's previous excavations at the Berestechko Battlefield, the Zboriv project made heavy use of historical records, cartographic evidence and archaeological fields testing methods. Beginning in 2002, the author, working in conjunction with the I. Kryp'iakevych Institute of Ukrainian Studies and Bohdan Strotsen, the regional director in charge of preservation of historical and cultural monuments for the Ternopil Oblast, began a joint survey, the purpose of which was identifying any possible remaining cultural resources associated with the military events of 1649 (Strotsen', 2003). Using the recently published map drawn by a participant of the battle which illustrates the disposition of forces and the extended fieldworks, along with the maps made by Kryp'iakevych during his visit to Zboriv and topographic maps of the region, we identified areas though to have the potential in yielding materials related to the battle. This information, when used in parallel with the limited descriptions of the battle, suggested areas for testing. During the course of a walking survey of Zboriv to identify areas severely impacted by modern development, discussions with area residents confirmed some of our reservations of how the 1649 battlefield was impacted by the trenches of First World War.

In 2002, our initial survey uncovered a significant amount of material. A wide variety of artifacts, many which date to the seventeenth century, were recovered during the course of the survey ${ }^{9}$. However, since these areas have been in agriculture for centuries, our initial analysis was restricted to distinctly seventeenth century military artifacts, specifically lead balls and arrowheads (Fig. 3). When we plotted the distribution of the seventeenth century military ordinance along an $\mathrm{X}$ and $\mathrm{Y}$ grid, we identified a line of dropped and impacted balls.

When we examined this distribution of military artifacts and compare them with the local topography, we see that all of these items are found along the military crest of a small rise. Since the "choice of ground on which to fight and the exact deployment of troops in battalia were based on sound military principles", it is clear that the topographic environment predetermined the establishment of the firing line in this particular location (Foard, 2001).

In addition to the recovered ordinance, we also examined artifacts such as buckles, buttons, melted pieces of lead, and quantities of hand wrought iron which may relate to military wagons or weapons. According to contemporary accounts and the recently discovered 1649 map, the crown forces built earthen fortifications to strengthen their battle lines. The recovery of so many metal hardware wagon parts found alongside of seventeenth century military ordinance suggests that the army added wagons to the defensive line. As so many of the objects were found along the same area as the dropped ordinance, including of a Tatar arrowhead, the likelihood of direct correlation between these artifacts is quite high. Based on this information, we believed that we have discovered the eastern portion of a battle line at Zboriv in an area not yet subject to residential or industrial development.

\footnotetext{
${ }^{8}$ For more information about the Commission and to view the results of the 2002 season, please go to the following web site: www.lviv.ua/cossacks

${ }^{9}$ At Zboriv the most common artifacts recovered from the survey data are from later battles in this area. Shrapnel balls, rifle cartridges, bullets and artillery shell fragments from the First World War and the Polish-Ukrainian War of 1919 litter the 1649 battlefield.
} 
In 2004, we returned to the area and conducted additional testing. Analysis of ammunition recovered from the two field seasons from this area of the battle line showed five discernable calibers and three types of ammunition in use. The first type of ammunition is represented by a large caliber round ball, between 16.6 and $17.0 \mathrm{~mm}$ in diameter and weighing between 19.5 grams and 25.3 grams, with the majority of the rounds weighing between 24 and 25 grams. Similar to the round balls mentioned above are those which are slightly heavier (28 grams) and have a diameter of $17.4 \mathrm{~mm}$ to $17.5 \mathrm{~mm}$ or between 0.68 to 0.69 of an inch. As balls of this type have only been recovered from the western edge of the battlefield, it is quite possible that these rounds were used by a particular military unit and are a variant of the slightly small round lead ball ammunition found throughout the battlefield. These are classic musket balls, which were used throughout the world from the seventeenth century up until the middle of the nineteenth century.

The second type of ammunition is a ball with an extended sprue intentionally left on the ball. These sprues are far more elaborate than a simple by-product of the casting process and the recovery of impacted balls with visible sprues indicates that these rounds were fired with the sprues still attached. Unlike eighteenth century cartridges, where both the ball and powder were inside a paper tube, makers of seventeenth century cartridges used the sprue to attach the ball to the paper tube. While such cartridges may have been in use by the mid-sixteenth century, in 1697, Saint Remy, a French scholar, "illustrated a cartridge with a ball attached by its sprue as the latest type (Remy, 1707) (Peterson, 1956). These are the most common type of seventeenth century small arms ordinance recovered at Zboriv and make up almost 50 percent of the assemblage.

Two sizes of extended sprue ammunition have been recovered at Zboriv. The most common rounds have a diameter between 12.6 and $13.3 \mathrm{~mm}$, or in inches, between 0.49 and 0.52 . These are the most common type of $17^{\text {th }}$ century small arms ordinance recovered at Zboriv and make up almost $50 \%$ of the assemblage. These balls are for a 50-caliber weapon. Less common are the slightly larger rounds that have a diameter of 14.1 to $14.7 \mathrm{~mm}$, or 0.55 and 0.58 of an inch. Like the balls that average between $15.0 \mathrm{~mm}$ to $16.0 \mathrm{~mm}$ in diameter, too few of these balls have been encountered to allow for a significant discussion.

The final type of ammunition recovered from Zboriv is buckshot. These are small, cast rounds which also exhibit an extended sprue. Though not commonly recovered, all the buckshot has a diameter between 9.1 and $9.5 \mathrm{~mm}$ or between 0.36 and 0.37 of an inch. While it may be possible that the buckshot may not relate to the 1649 engagement, the degree of white oxide patina is indicative of old age.

What is the significance of this mathematical data? While it may be possible to recognize particular units based on the use of a particular weapon, the recovered ammunition challenges some of our understandings about the Cossacks. First of all, the standardization of ammunition into distinct sizes is a good indication that the firearms used by the troops were also standardized. Such a level of standardization is not uncommon amongst seventeenth century standing armies, but relatively unheard of in tribes or rebel armies. During the course of the American Revolution, one Pennsylvania Committee of Safety member complained about having to supply balls of seven different diameters to the American rebel army two years into the rebellion. (Neumann, 1967) Musket balls recovered at the 1782 Battle of Blue Licks indicated an even greater discrepancy in ammunition calibers, with ten distinct calibers being noted (Mandzy, 2008). Ammunition recovered from seventeenth century Native American sites appears in even greater variations. Bradley and Puype, who focused on the Onondaga and Seneca Iroquois respectively, argued that the absence of readily identifiable clustering patterns suggests a lack of any sort of ammunition standardization on Native American sites (Puype, 1985) (Bradley, 1987). This thesis is supported in part by the wide variety of calibers recovered from the 1686 wreck of the Le Belle (Bruseth, James E., Turner, Toni S., 2005).

Secondly, the presence of sprue ammunition indicates that the troops at Zboriv were using cartridges. The use of cartridges simplified the loading process and resulted in a faster rate of fire. Previously, musketeers relied upon bandoleers of pre-measured powder charges. Lord Orrery, a 
seventeenth century military writer also noted that "bandeleers are often apt to take fire, especially if the matchlock musket be used." (Peterson, Arms and Armor in Colonial America 1526-1783, 1956) Although mounted units used small metal cartridge boxes as early as the second half of the sixteenth century, the overwhelming majority of European infantry continue to rely upon bandoleers. Bandoleers were cheap to produce and continued to be found in European arsenals until the end of the century. Infantry cartridge boxes, however, were new and were in use in Ukraine as early as $1649^{10}$.

The recovered military ordinance challenges many of the commonly held assumptions of the Cossack armies of the mid-seventeenth century. Most scholars agree that the Cossack rebels wanted to create a new political system that would replace the religious, economic and culture elite in the southeastern territories of the Commonwealth, but few also note that the military innovations employed by Cossacks were just as revolutionary. Not only were the rebel armies under the direction of innovative leaders who had significant military talent and expertise in engineering, but the weapon systems used by the rebels were the most modern and technically developed in both Europe and Asia. Clearly, these armies may have looked rather raggedy, especially when compared to the silver and gold encrusted troops of the Commonwealth, but the Cossack army was a professional force equal to any on two continents.

In 2005, Bohdan Strotsyn carried out salvage excavations on the section of the Zboriv Battlefield impacted by the construction of a gasoline station (Strotsyn, 2007). As a result of our previous study of the battlefield, this area was believed to be sensitive for archaeological resources and it was postulated that the Polish defensive line ran through this location. Excavation for the underground storage tanks had begun previous to any sort of archaeological survey and it was doubtful that any information could be collected. After an extensive legal battle where the construction company was found to have disregarded the designation of the battlefield areas as an archaeological site, an agreement was reach and as part of the mitigation plan, Strotsyn excavated a series of trenched in the area where the gas station complex was to be built. In his excavation of the territory surrounding the already installed storage tanks, he found traces an earthen redoubt which was built as part of the 1649 defensive line.

In 2006, we returned to Zboriv to locate additional sections of the battlefield, many of which are now encroached by settlement ${ }^{11}$. As the southern section of the 1649 defenses was the most impacted by the First World War, we directed our efforts along the northern and northeastern areas of the battlefield. Working on small parcels of land between existing structures, we were able to recover a number of seventeenth century artifacts which related to the battle. Among the musket balls and pottery shards recovered along the surface, the recovery of an octagonal pewter handle with traces of gold leaf within the Polish line illustrates how richly equipped the forces of the Commonwealth were at the time of the battle. The recovery of a similar style two-pronged fork from among the slain at the Berestechko Battlefield is thought to represent booty previously looted by Cossacks or peasants from the nobility (Sveshnikov, 1993).

In spite of the difficulties of working in developed areas, we were able to successfully conduct a historical-topographic survey of the battlefield. As a result of our six-week survey, located an independent redoubt within the Polish line, the area of the Cossack battery, the probable location of the Tatar camp, the church which the Cossacks captured and from which they fired on the entire Polish defensive line. From this information we were able to postulate the location of the Cossack camp.

The location of the Cossack camp was a great mystery and the predominant opinion was that it was located a few kilometers away from the Polish defense line. The initial discovery of a heavily worn large copper medallion, two possible seventeenth century coins and both fired and dropped musket balls

\footnotetext{
${ }^{10}$ The leather and wood cartridge boxes were also recovered at the Berestechko battlefield. The Berestechko cartridge boxes are though to be among the earliest known examples of infantry cartridge boxes used in Europe but it is more than likely that the Swedes first developed infantry cartridge boxes. Cartridge boxes quickly became popular and continued to be used until the end of the nineteenth century.

${ }^{11}$ This research was made possible by a Fulbright-Hays Faculty Research Fellowship and through the support of Morehead State University.
} 
a little more than three hundred and fifty meters from the Polish line was initially confusing, but when we compared the location of these finds with the 1649 map, it was postulated that we had found the outer limits of Cossack camp. Additional testing in this area produced various personal and military artifacts, including a fragment of a horse bridle bit, a cast lead buckle, a button, an incised copper signet ring with two possible Cyrillic letters, two seventeenth century pottery sherds, and an unusual impacted musket ball which was fired into the perimeter of the Cossack camp.

The impacted musket ball in question was round and did not look unusual, but after washing, it was discovered that the ball was only partially made of lead. At the core of the ball was a stone pebble, part of which had chipped off when the bullet had hit a target. While the ballistic of such a musket ball, with its irregular center of gravity, was undoubtedly inferior to a spherical solid lead ball, its use suggests a temporary measure, most likely associated with a shortage of lead. Similar balls have been found in Ukraine near Pyliavtsi and have been associated with the 1648 battle fought in this location (Pohorilets, 2007). While the pebble lead jacketed balls from Pyliavtsi appear to for a smaller caliber weapon, perhaps representing a unit of cavalry, the presence of extended sprue ordinance suggests that they relate to the events of 1648 .

The recovery of such a pebble lead jacketed musket ball at Zboriv most likely indicates a shortage of lead, rather than any special type of experimental ammunition. With the destruction of army's supply wagons during the initial round of fighting, many supplies were undoubtedly lost. Once the Polish army became besieged at Zboriv, whatever resources were available were put into use. The documentary evidence provides numerous examples when besieged armies were forced to strip the lead from buildings, or to collect and reuse expended ammunition, and even use horseshoe nails as bullets (Sveshnikov, 1993). In 1662, for example, the Polish nobleman Ian Pasek writes that when faced with a lack of musket balls, his troops used small stones and horseshoe nails in place of bullets (Pasek, 1968). Thus, as the manufacture of lead jacketed stone pebble musket balls is a strong indication of a critical shortage of military supplies, the use of such stop-gap ammunition suggests significant logistical problems within the Polish camp.

The discovery of the Cossack camp, as well as the identification of the locations of the Cossack battery and the church from which the Cossacks fired into the Polish camp indicates of how critical the military situation had become for the monarchy. The location of the Cossack camp just over three hundred and fifty meters from the Polish line is not just a random distance, it is in fact, just a little beyond the maximum range of musket fire (Fuss, 2003). The placement of the Cossack camp served not only as a physiological barrier to the troops trapped inside the defensive line, but serve two practical purposes as well - to provide an observation point from which to safely watch the enemy and as a way of pinning the king's army in this location to prevent the possibility of any breakout. Similarly, the placement of the Cossack battery across the river allowed the rebels to fire at the enemy without any chance to being counteracted.

The information recovered from the three field seasons have forced us to ask more questions about the Battle and the Treaty. It is very clear that the Polish army was hemmed in from two sides and Storozhenko is quite correct in saying that it was only a matter of time before the Polish line was stormed or starved into submission. The recovery of the lead jacketed stone pebble musket ball which was fired into the direction of the Cossack camp underlines how critical the situation was for the monarchy. The ability to place an enemy into such position is a sterling example of Khmelnytskij's abilities as military commander.

The more pressing questions is how to interpret the Treaty. Clearly, Khmelnytskij was duplicitous in his relations with existing monarchs and heads of state. Not only did he pledge his allegiance to the Tatar Khan, but he took up arms against his monarch. While numerous examples exist in Early Modern Europe were lords rebelled against their kings, Khmelnytskij was not a lord. It is for this very reason that Khmelnytskij stakes a claim to his nobility when he writes to the king during the course of the Zboriv negotiations (Hrushevskyj, 2002). Storozhenko is correct in saying that Khmelnytskij needed the Tatar khan to arbitrate in his negotiate with Jan Casimir, since no monarch (and all monarchs are chosen by 
God) would belittle himself to negotiate with mere noble. And Khmelnytskij was only a Cossack. As a result of these negotiations, Khmelnytskij is no longer cursed by the monarchy, but rather was recognized as the legal administrator of the Ukrainian principality. Unlike the monarchy of the Commonwealth, which maintained no large standing army, Khmelnytskij's register of 40,000 Cossacks allows him to impose his will at any time.

\section{Conclusions}

As a result of the treaty, Khmelnytskij become the de facto autocrat of Ukraine. Internal attempts to challenge Khmelnytskij's authority were quickly settled and the perpetrators dealt with. Realizing that the structure of the Hetmanate would not allow him to establish a dynasty, Khmelnytskij turns his attention to Moldavia, where he strove to place his son on the thrown. Failures in his Moldavian adventures came back to haunt the hetman, as he was defeated at Berestechko. Unable to regain the terms laid out in the Treaty of Zboriv with the Polish monarchy, Khmelnytskij tried to obtain a similar settlement with different rulers. While Hrushevsky pointed out the striking similarities between the Treaty of Zboriv and the 1654 Pereiaslav Accord, he offered no explanation (Hrushevskyj, 2002). If the Treaty of Zboriv did indeed serve as the model for the Pereiaslav Accord, then perhaps we need to reexamine the Treaty of Zboriv.

In reality, the Zboriv Treaty was a win for all three negotiators. The historian Myron Korduba is correct in seeing Zboriv as a Tatar victory, since the Tatars received both financial rewards and the right to collect slaves on their return to the Crimea (Basarb, 1982). In a similar manner, Khmelnytskij and the Cossack leadership also won, as they received autonomy from the Polish nobility, along with a host of other religious and secular concessions. The Polish monarchy and the armies trapped at Zboriv and Zbarazh also were victorious, in that each of the living got to go home. More importantly, the institution of the Commonwealth was able to survive and the nobility could continue to fight against the Swedes and the Turks. The king's dismissal of the noble militia after the signing of the Treaty and the ratification of the Zboriv Treaty by the Polish Diet in January 1650 suggests that the Crown viewed the Treaty as a positive development ${ }^{12}$. The losers of the Treaty were those who had no voice at the negotiations - the rank and file peasants who had fought against the Commonwealth and the urban residence of Ukraine who within a few days were to be captured and sent into Tatar slavery. Yet in the mindset of the seventeenth century negotiators, the lower classes were expendable and not worthy of comment. The fate of Hrytsko Turchyniak, a resident of Zboriv who took part in the attacks on the Polish nobility during Khmelnytskij's time in Zboriv (perebuvannia), like so many of his peers who rose up against the existing status quo, remains unknown ${ }^{13}$.

Perhaps the final question about the entire campaign is how much of it was planned and how much resulted in luck. Unfortunately, the archaeological and topographic evidence does not address these issues and the historical evidence is too fragmentary to provide a definitive interpretation. Clearly, the ongoing siege of Zbarazh provided the ideal mechanism for drawing the king to the battlefield, and once relief force was assembled, Khmelnytskij was presented with the perfect opportunity to deal with the monarchy itself. The initial attack at Zboriv placed the monarchy on the defensive and removed the possibility of it conducting further offensive operations. While we have no evidence that the entire campaign was planned in expectation of such a development, our research shows that Khmelnytskij had clearly trapped the king and his army at Zboriv. Like General Vo Nguyen Giap at Dein Bien Phu a few centuries later, Khmelnytskij had no need of further attacking the enemy once he achieved his objective. Indeed, the death or capture of the monarch could have resulted in a general rising against the Cossacks, which in turn would have forced Khmelnytskij to turn to the more radical elements within

${ }^{12}$ Decree of Ian Casimir, Lviv City Archives, Tsentralinyj Derzhavnyj Istorychnyj Archiv Ukrainy, m. L'viv (TsDIAL), fond 9, op. 1, spr 399, str 292-293.

${ }^{13}$ Terebovlians'kyj Hrods'kyj Sud, TsDIAL, fond 17, op. 1, spr. 131, str. 615-167. 
his forces. Undoubtedly, such a turn of events would have placed an even greater reliance of the Cossacks on the Tatars. Clearly, it was not in the Cossack leader's interests to pursue such a potentially self-destructive policy.

One thing is clear, however. By the time the monarchy was trapped in Zboriv with no hope of escape, it was in Khmelnytskij's interest to force a negotiated settlement. Circumstance placed him in the perfect position of achieving recognition as ruler of Ukraine. Storozhenko is more than likely correct in stating that attacks on the earthen fortification would have required a greater military effort than the previous attacks on the enemy, but such statements are irrelevant. Khmelnytskij was too shrewd political to waste his opportunity of achieving recognition as de facto ruler of Ukraine by continuing his attacks.

A few years later, the wars resumed and new treaties were signed. Khmelnytskij's numerous attempts to reinstate the points of the Zboriv Treaty in all additional accords is undisputable evidence that the hetman did not simple settle for the Treaty of Zboriv. Clearly the Treaty of Zboriv was incapable of satisfying all members of society, but that was not its intent. The Cossack leadership was to be the new nobility and the Orthodox Church was to replace the Latins.

When comparing Khmelnytskij with other rebel leaders in world history, his creation of an autonomous Ukrainian Cossack principality was a remarkable achievement. Though people may lament that Khmelnytskij did not pursue a policy that included the interests of all economic classes, one cannot judge seventeenth century behavior by using nineteenth century values. While many in Europe rose up against their monarchs, Khmelnytskij attained that which many only dreamed of. Like the Czech General and Hussite leader John Źiźka before him and Theodor Koscuiczko a hundred and fifty years later, that which he created did not last, but that in no way takes away from he accomplished. For that reason, and for that reason alone, Zboriv represents a watershed event in the history of Europe.

\section{References}

[1] Akty otnosiashchiesia k istorii Iuzhnoi i Zapadnoi Rossii (T. 3). (1861). St. Petersburg.

[2] Alexandrowicz, S. (1995). Plany Obronnych Obozów wojsk Polskich pod Zbara'zem i Zborowem z Roku 1649. Fortyfikacja(1), 15-23.

[3] Antonovych, V. (1885.). Istoriia velikago kniazhevstva litovskago do smerti kn. Olgerda (T. 1). Kiev.

[4] Babits, L. E. (2001). Fields of Conflict: Progress and Prospect in Battlefield Archaeology. y Book Archaeology of the Cowpens battlefield (c. 118). BAR International Series.

[5] Baraboj, A. Z., Bevzo O. A., eds., P'ier Sheval'e (Pierre Chevalier). (1993). Istoria viiny kozakiv proty Pol'shchi (Histoire de la Guerre des Cosaques contre la Polocne). Kiev: Tomiric.

[6] Basarb, J. (1982). Pereiaslav 1654: a Historiographical Study,. The Canadian Institute of Ukrainian Studies, Edmonton, 179-187.

[7] Bradley, J. W. (1987). Evolution of the Onondaga Iroquois. Syracuse: Syracuse University Press.

[8] Braichevsky, M. (1972). Pryiednannia chy vozziednannia? Krytychni zauvahy z pryvodu odiniei kontseptsii. Toronto: Novi Dni.

[9] Bruseth, James E., Turner, Toni S. (2005). From a Watery Grave: the Discovery and Excavation of La Salle's Shipwreck La Belle. Texas A \& M University Press.

[10] Dzyra, I. I. (1971). Litopys Samovydtsia. Kiev: Naukova Dumka.

[11] Foard, G. (2001). The archaeology of attack: battles and sieges of the English Civil War. y P. F. Pollard, in Fields of Conflict: Progress and Prospect in Battlefield Archaeology. BAR International Series 958.

[12] Frąś, L. (1932). Obrona Zbarźa w r. 1649. Krakow.

[13] Fuss, N. (2003). A Theoretical Examination of the Effectiveness of 18th Century Musketry. 33(4), 2-11.

[14] Gajecky, G. (1978). The Cossack Administration of the Hetmanate. Massachusetts: Harvard Ukrainian Research Institute, Cambridge.

[15] Hrushevskyj, M. (2002). History of Ukraine Rus', vol. 8, The Cossack Age, 1626-1650. Edmonton: Canadian Institute of Ukrainian Studies Press.

[16] Iavorsky, M. (1928). Istoriia Ukrainy v styslim narysi. Kharkiv. 
[17] Konyskogo, G. e. (1846). Istoria Rusov' ili Maloj Rossii. Moscow: Universytetskoj Typografij.

[18] Korzon, T. (1912). Dzieje Wojen i Wojskowości w Polsce (T. 2). Krakow.

[19] Kostomarov, M. (1990). Malorossyjskyj getman Zynovyj-Bohdan Khmelnytskyj. Kiev: Istorycheskye proizvedenyia, Lybid'.

[20] Kozachenko, A. I. (1954). Bor'ba Ukrainskogo naroda za vossoedinenie s Rossiei. Moscow.

[21] Kryp'iakevych, I. (1990). Bohdan Khmelnytskij. L'viv: Svit.

[22] Kubala, L. (1909). Oblęźenie Zbaraźa i Pokój pod Zborowem (T. 122). Krakow: Biblioteczka Uniwersytetów Ludowych i Młodzieźy Szkolnej.

[23] Lees, W. B. (1994). When the shooting stopped, the war began. Look to the earth: Historical archaeology of the American Civil War, 39-59.

[24] Lypynsky, V. (1920). Ukraina na perelomi, 1657-1659. Vienna.

[25] Mandzy, A. (2008). An Archaeological Survey of the Battle of Blue Licks.

[26] Mats'kiv, T. (1985). Zborivs'kyj dohovir u svitli nimets'koi j anhlijs'koi presy z 1649 r. (T. 38). Toronto: Zborivshchyna, Naukove Tovarystvo im. Shevchenka, Ukrains'kyj Arkhiv, Zborivshchyna.

[27] Neumann, G. C. (1967). The History of Weapons of the American Revolution. New York: Harper and Row.

[28] Orlyk, P. (1958). Déduction des droits de l'Ukraine, 1712-13. the Annals of the Ukrainian Academy of Arts and Sciences in the United States.

[29] Pasek, I. (1968). Pamiętniki. Wroclaw.

[30] Peterson, H. L. (1956). Arms and Armor in Colonial America 1526-1783. Harrisburg, Pennsylvania,.

[31] Peterson, H. L. (1956). Arms and Armor in Colonial America 1526-1783. Harrisburg, Pennsylvania.

[32] Pohorilets, O. (2007). Do problemy poshuku mistsia bytvy pid Pyliavtsiamy 11-13 beresnia 1648r. the XVI Conference, New Research on Cossack Heritage Sites in Ukraine. Kiev.

[33] Pokrovsky, M. (1933). A Brief History of Russia. New York: International Publishers.

[34] Puype, J. P. (1985). Dutch and Other Flintlocks from Seventeenth Century Iroquois Sites Research Records. Proceedings of the 1984 Trade Gun Conference. 18. Rochester: Rochester Museum and Science Center.

[35] Remy, P. S. (1707). Memoires d'Artillerie. Paris.

[36] Scott, D. D., Richard A. Fox, Jr. (1987). Archaeological insights into the Custer battle: an assessment of the 1984 field season. Norman.

[37] Scott,D. D., Fox R. A., Jr., Connor M. A. and Harmon D. (1989). Archaeological perspectives on the Battle of the Little Bighorn. Norman.

[38] Shevchenko, F. I. (Ред.). (1995). Reiestr Vijs'ka Zaporoz'koho 1649 r. Kiev: Ukrains'ka Academia Nauk, Haukova Dumka.

[39] Sivilich, D. М. (без дати). Analyzing musket balls to interpret a Revolutionary War Site. Historical Archaeology, 30(2), 101-109.

[40] Smolij, V., Stepankov, V. (203). Bohdan Khmelnyts'kyj. Kiev: Al'ternatyv.

[41] Storozhenko, I. C. (1996). Bohdan Khmelnytskyj i voienne mystetstvo u vyzvol'nij vijni ukrains'koho narodu seredyny XVII stolittia. Dnipropetrovs'kyj derzhavnyj universytet,.

[42] Strotsen', B. S. (2003). Zvit pro arxeolohichni rozvidky v okolytsiakh m. Zborova (Ternopil's'ka obl.) u 2002 r. Ternopil': Ternopil's'ka oblasna komunal'na inspektsia okhorony pam'iatok istorii ta kul'tury.

[43] Strotsyn, B. (2007). Novi materialy pro mistse Zborivs'koi bytvy. Arkheolohiia zakhodu ukrainy. L'viv.

[44] Subtleny, O. (1988). Ukraine, A History. Toronto: University of Toronto Press.

[45] Sveshnikov, I. K. (1993). Bytva pid Berestechkom. L’viv: Slovo.

[46] Sysyn, F. (1985). Between Poland and the Ukraine: the Dilemma of Adam Kysil 1600-1653. Massachusetts: Harvard Ukrainian Research Institute, Cambridge.

[47] Teodor Mats'kiv. (1985). Zborivs'kyj dohovir u svitli nimets'koi j anhlijs'koi presy z 1649 r. Zborivshchyna, Naukove Tovarystvo im. Shevchenka, Ukrains'kyj Arkhiv, 38, 33-50.

[48] Thordeman, B., Noörlund P. and Bo E. (1939). Ingelmark, Armour from the Battle of Wisby, 1361. Stockholm: Kungl. Vitterhets Historie OCH Antikvitets Akademien.

[49] Tomashivsky, S. (1913). Odyn moment pid Zborovom 1649 r. Zapysky Naukovoho Tovarystva imeny Shevchenka.

[50] Vernadsky, G. (1941). Bohdan, Hetman of Ukraine. New Haven: Yale University Press.

[51] Yakowenko, N. (2006). An Outline History of Medieval and Early Modern Ukraine, 3rd Revised and enlarged edition. Kiev: Krytyka. 


\section{ПОЛЕ БИТВИ 1649 РОКУ ПІД ЗБОРОВОМ: ІДЕНТИФІКАЦІЯ МІСЦЯ ТА ПЛАНУВАЛЬНА РЕКОНСТРУКЦІЯ}

Анотація. У 2001 р. д-р А. Мандзій, працюючи з науковиями у Польщі, і в Україні, ініціював створення комісії для вивчення козацьких полів битв. Об'єктом для досліджень було вибрано поле битви під Зборовом 1649 р. Подібно до попередніх розкопок на полі бою в Берестечку, проєкт “Зборів” активно використовував аналіз історичних документів, картографічні дані та методи тестування археологічних полів. Починаючи з 2002 року, група дослідників, щуо прачювали за керівництва д-ра Мандзія спільно з Інститутом українознавства імені І. Крип'якевича і кафедрою архітектури та консервації Львівської політехніки, регіональною владою зі збереження пам'яток історії та культури Тернопільської області, розпочали спільне дослідження, метою якого було: виявити можливі інші культурні ресурси, пов'язані з військовими подіями 1649 р. Дуже корисним було використання нещодавно опублікованої карти, учасника битви, яка ілюструє дислокацію сил. Було реалізовано польові дослідження, у зіставленні з аналізом карт, зокрема, картою битви історика I. Крип'якевича та топографічними картами регіону. Були визначені території безпосередніх подій битви, а також райони, що мають потенціал для отримання матеріалів, пов'язаних із битвою. Ця інформація допомогла визначити території для обстеження і тестування. Під час опитування мешканців Зборова з метою виявлення районів битви підтвердилися деякі застереження щодо існування на околиці міста траншей з часу Першої світової війни. У 2002 роиі під час первинного інструментального дослідження було виявлено значну кількість матеріалів - найрізноманітнімі артефакти, багато з яких датовані XVII століттям. Однак, оскільки иі райони протягом століть були в сільськогосподарському використанні, до аналізу бралися лише чіткі артефакти XVII ст., зокрема свинцеві кулі та наконечники стріл. Коли виконувалося картографування розподілу військових артефактів сімнадиятого століття по сітиі X та Y, визначалися лінії опущених та уражених куль. Це був базовий матеріал для гіпотетичної реконструкиї розпланування польових укріплень 1649 p.

Ключові слова: місто Зборів, поле битви, козачька та польська армія, ХVII століття, гіпотетична реконструкиія. 